\title{
Performance of tubular reverse osmosis for the desalination/ concentration of a municipal solid waste leachate
}

\author{
JJ Schoeman ${ }^{1 *}$ and LJ Strachan ${ }^{2}$ \\ ${ }^{1}$ University of Pretoria, Department of Chemical Engineering, Water Utilisation Division, Pretoria 0002, South Africa \\ ${ }^{2}$ Durban Solid Waste, Durban Metro City Council, PO Box 1038, Durban 4000, KwaZulu-Natal, South Africa
}

\begin{abstract}
Municipal solid waste leachate (MSWL) has the potential to pollute the water environment and to affect biological treatment processes adversely if not properly handled. Reverse osmosis (RO) has the ability to remove both organics and inorganics effectively from effluents. Therefore, RO was evaluated for the treatment of MSWL. It was found that both cellulose acetate and polyamide RO membranes should function effectively for the treatment of the leachate and that it should be possible to control membrane fouling with chemical cleaning. The polyamide membranes, however, performed somewhat better than the cellulose acetate membranes for the treatment of the leachate. The quality of the treated leachate with the exception of ammonia-nitrogen and COD should comply with the quality requirements for discharge into the water environment. Biological treatment processes are effective in complete removal (to only traceable levels) of ammonia-nitrogen and biodegradable COD. The quality of the treated effluent further complies with the quality requirements (chloride and heavy metals) for discharge into the municipal biological treatment system. The capital and operational cost of a $250 \mathrm{~m}^{3} / \mathrm{d}$ tubular reverse osmosis (TRO) plant is estimated at R1.95 m. and R11.45/ $\mathrm{m}^{3}$, respectively.
\end{abstract}

Keywords: reverse osmosis, leachate treatment, membrane fouling, membrane cleaning, effluent quality, treatment costs

\section{Introduction}

Municipal solid waste (MSW) generation is increasing with industrial and commercial growth (Lin and Chang, 2000). Landfilling is at present the most popular and economical way of solid waste disposal and leachate generated from a landfill site poses a major problem of landfill disposal of MSW due to potential ground- and surface water pollution (Usher et al., 2004). Proper treatment of the leachate is therefore a challenging problem confronting the authorities.

Landfill leachate has been generally known as a highstrength wastewater that is most difficult to deal with. This is due primarily to its large variability of organic and inorganic and heavy metals contents, strongly depending on the age and type of solid waste of a landfill site (Knok and Jones, 1979). Satisfactory treatment of leachate is thus no easy task.

The most popular treatment of landfill leachate in the past was anaerobic digestion or the aerobic sludge method (Lema et al., 1988). These methods were known to be inadequate in handling such a difficult treatment task. In the more recent decades, a search for alternative treatment methods had focused on various sophisticated technologies. These included advanced biological, chemical and physical treatment methods. Robinson (2000), Strachan et al. (2000; 2004) and Laitinen et al. (2006) studied leachate treatment using the sequencing batch reactor (SBR) method. Percival et al. (1997) studied aerobic treatment of a high-strength leachate preceded by ion-exchange and lime addition to effect inorganic removal prior to biological treatment. Imai et al. (1998) developed an efficient biological activated

\footnotetext{
* To whom all correspondence should be addressed.

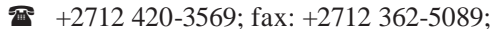

e-mail: apie.schoeman@up.ac.za

Received 12 December 2007; accepted in revised form 12 January 2009.
}

carbon fluidised bed process and Lim et al. (2009) studied treatment of landfill leachate using palm-shell activated carbon. Chemical oxidation using strong oxidising agents such as Fenton's reagent, photo-assisted $\mathrm{H}_{2} \mathrm{O}_{2}$, ozone or UV-VIS light was reported by Gau and Chang (1996) and Rivas et al. (2005). Membrane processes have received considerable attention in the past decades, as reported by many investigators (Rautenbach and Linn, 1996; Peters, 1998; Ushikoshi et al., 2002; Hurd et al., 2001; Wintgens et al., 2006; Belkhouche et al., 2009). In fact, Gierlich and Kolbach (1998) indicated that membrane technology has been widely practised in many European countries in dealing with leachate treatment. The biggest problem encountered with membrane treatment of leachate is membrane fouling while an advantage is that salts and heavy metals can be removed from the leachate.

Review of the literature has indicated that physical (membrane) and chemical methods appear to offer quite good alternatives to biological treatment. Tubular reverse osmosis (TRO) should be a very suitable technology for the treatment of hazardous leachate with a high suspended solids and a relatively low TDS concentration. This type of leachate is produced by many landfill sites in South Africa and has the potential to pollute the water environment and to adversely affect biological treatment processes. However, very little information is available in South Africa regarding the performance of TRO for the treatment of leachate. The objectives of this investigation were therefore to evaluate the performance of TRO for the treatment of a leachate and to determine the preliminary economics of the process.

\section{Experimental}

\section{Cellulose acetate membranes}

Approximately $100 \ell$ MSWL (pH adjusted to 6.5 with $\mathrm{H}_{2} \mathrm{SO}_{4}$ ) were treated in the batch mode (4000 $\mathrm{kPa}$ inlet pressure) in 
Brine

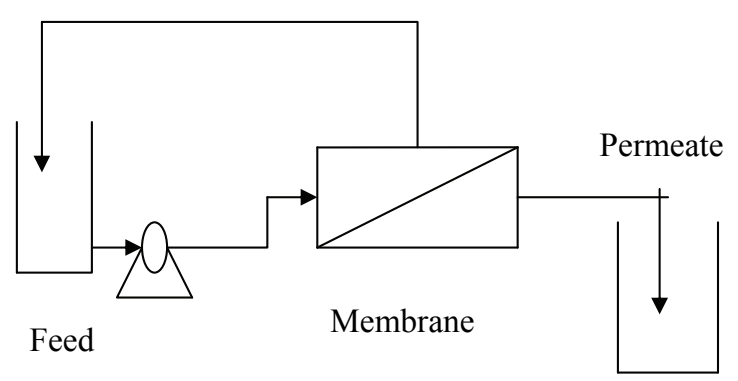

Figure 1

Experimental set-up for the batch treatment of the municipal solid waste leachate (MSWL)

a TRO pilot plant (membrane area $1.75 \mathrm{~m}^{2}, 1$ module) (Schoeman et al., 2004). The experimental set-up is shown in Fig. 1. Reverse osmosis (RO) was terminated at a water recovery of approximately $70 \%$. The clean water flux (CWF) was measured before and after the run. Permeate flux (PF) was measured as a function of percentage water recovery. The chemical composition of the RO feed, product and brine was also determined. (Note: sponge-ball (SB) cleaning and flow reversal were used)

\section{PCI AFC 99 membranes}

The same experiment as described in the previous paragraph was conducted with the PCI AFC 99 polyamide membranes. No $\mathrm{pH}$ adjustment of the $\mathrm{RO}$ feed was conducted in this case. The membrane area was $0.81 \mathrm{~m}^{2}$ ( 1 module).
Anti-Scalant

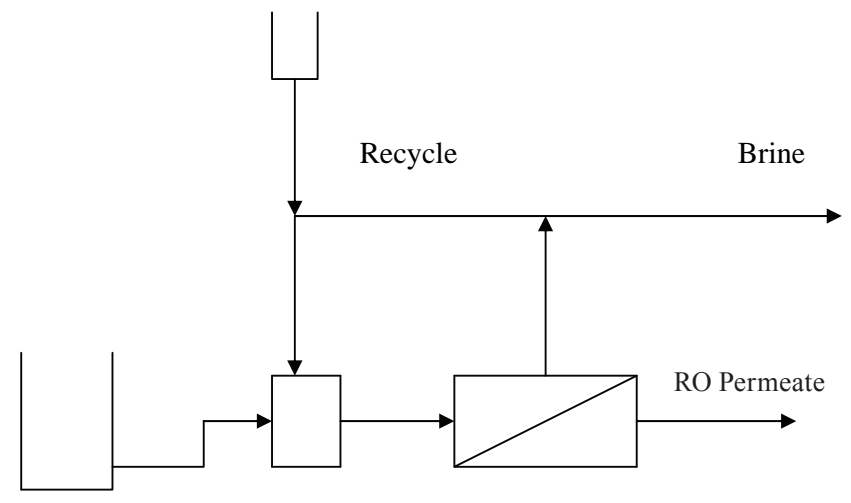

Leachate
RO Membrane

Figure 2

Experimental set-up for the feed-and-bleed RO system

\section{Results and discussion}

\section{Characteristics of the leachate}

The chemical composition of the leachate is shown in Table 1.

The salinity (conductivity), $\mathrm{COD}, \mathrm{NH}_{4}-\mathrm{N}, \mathrm{PO}_{4}-\mathrm{P}$ and $\mathrm{Na}$ concentration levels are too high for discharge into the water environment. The chloride concentration level is too high for discharge into the sewer system. It is also clear that the $\mathrm{Cr}, \mathrm{Mn}$, $\mathrm{Fe}$ and $\mathrm{Pb}$ concentration levels are too high for discharge into the water environment. Therefore, the leachate should be treated prior to discharge into the water environment or the sewer.

\section{Feed-and-bleed RO tests}

Reverse osmosis runs (pilot study) were conducted in the feed-and-bleed mode of operation at Bisasar Road Landfill Site (Schoeman et al., 2004) (Fig. 2). The membrane areas for the cellulose acetate and polyamide membranes (PCI-AFC99) were 1.75 and $0.81 \mathrm{~m}^{2}$, respectively (one module each). The $\mathrm{pH}$ of the feed water to the cellulose acetate and polyamide membranes was adjusted with hydrochloric acid to pH 6.2 to 6.5 and 7 to 7.2 , respectively. An antiscalant, Flocon $260(12.5 \mathrm{mg} / \ell)$, was dosed during RO treatment (cellulose acetate), while Permatreat 391 $(11 \mathrm{mg} / \ell)$ was dosed with the polyamide membranes. Water recovery was kept at approximately $70 \%$. The CWF was determined at the start of the runs and then once a day after a water rinse for $30 \mathrm{~min}$. Clean water flux was also determined before and after membrane cleaning. Cleaning of the cellulose acetate membranes was conducted with nitric acid (NA), sodiumtripoly phosphate (STPP)/EDTA, citric acid (CitA), Ultrasil 50, EDTA/sodium laurel sulphate (SLS) and phosphoric acid (PhosA) solutions (Schoeman et al., 2004). The polyamide membranes were cleaned with hydrochloric acid and Ultrasil 10 (Schoeman et al., 2004). Sponge-ball (SB) cleaning (30 min) with flow reversal was used (cellulose acetate). The RO product flux was measured as a function of time. The chemical composition of the RO feed, product and brine was also determined.

\begin{tabular}{|l|c|c|c|c|c|}
\hline \multicolumn{7}{|c|}{ TABLE 1 } \\
\hline Constituent & \multicolumn{2}{|c|}{$\begin{array}{c}\text { Bisasar Rd } \\
\text { raw leachate }\end{array}$} & $\begin{array}{c}\text { "Special" } \\
\text { standard } \\
\text { for } \\
\text { discharge }\end{array}$ & $\begin{array}{c}\text { General } \\
\text { standard } \\
\text { for } \\
\text { discharge }\end{array}$ & $\begin{array}{c}\text { Discharge } \\
\text { to Durban } \\
\text { Metro } \\
\text { sewer }\end{array}$ \\
\hline $\mathrm{pH}$ & 8.0 & 8.0 & 5.0 to 7.5 & 5.5 to 9.5 & 6.0 to 10.0 \\
\hline $\mathrm{Conductivity}$ & 1291 & 1650 & 250 & 250 & \\
\hline $\mathrm{COD}^{2}$ & 2427 & 2000 & 30 & 75 & \\
\hline $\mathrm{BOD}_{5}$ & 320 & 955 & & & \\
\hline $\mathrm{BOD}_{5} / \mathrm{COD}$ & 0.13 & 0.48 & & & \\
\hline $\mathrm{NH}-\mathrm{N}$ & 1271 & 980 & 1.0 & 10.0 & \\
\hline $\mathrm{Cl}$ & 1790 & 2625 & & & 1000 \\
\hline $\mathrm{PO}-\mathrm{P}$ & 8.4 & 6.9 & 1.0 & 1.0 & \\
\hline $\mathrm{SO}$ & 48 & 149 & & & 250 \\
\hline $\mathrm{Na}$ & 897 & 1620 & $50>$ influent & $90>$ influent & \\
\hline $\mathrm{Mg}$ & 56 & 141 & & & \\
\hline $\mathrm{K}$ & 1022 & 1150 & & & \\
\hline $\mathrm{Ca}$ & 36 & 70.6 & & & \\
\hline $\mathrm{Cr}$ & 0.05 & 0.17 & 0.05 & 0.05 & 20 \\
\hline $\mathrm{Mn}$ & 0.12 & 0.382 & 0.1 & 0.4 & 50 \\
\hline $\mathrm{Fe}$ & 2.70 & 3.16 & 0.3 & & 50 \\
\hline $\mathrm{Ni}$ & 0.09 & 0.20 & & & 50 \\
\hline $\mathrm{Cu}$ & $<0.01$ & 0.008 & 0.02 & 1.0 & 50 \\
\hline $\mathrm{Zn}$ & 0.08 & 0.025 & 0.3 & 5.0 & 50 \\
\hline $\mathrm{Cd}$ & $<0.01$ & 0.004 & 0.05 & 0.05 & 20 \\
\hline $\mathrm{Pb}$ & $<0.02$ & 0.126 & 0.1 & 0.1 & 20 \\
\hline $\mathrm{Note}$ & & & & \\
\hline
\end{tabular}

Note All results are in $\mathrm{mg} / \mathrm{l}$ except for $\mathrm{pH}$ value and electrical conductivity $(\mathrm{mS} / \mathrm{m})$. 
Figure 3

Permeate flux as a function of $\%$ water recovery (cellulose acetate)

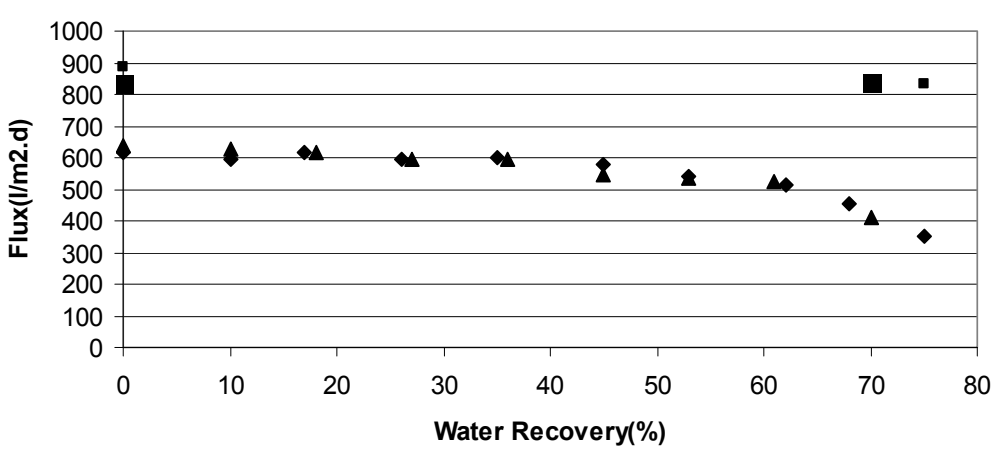

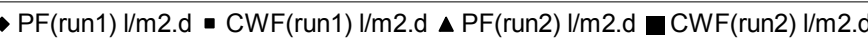

\begin{tabular}{|c|c|c|c|c|}
\hline \multicolumn{5}{|c|}{$\begin{array}{c}\text { TABLE } 2 \\
\text { Chemical composition of RO feed, permeate } \\
\text { and brine }\end{array}$} \\
\hline Constituent & Feed & Permeate & Brine & Removal \% \\
\hline TDS & 8975 & 348 & 4695 & 96.1 \\
\hline TSS & 29 & 6 & 48 & 79.3 \\
\hline $\mathrm{NH}_{3}-\mathrm{N}$ & 882 & 82 & 1770 & 90.7 \\
\hline $\mathrm{PO}_{4}-\mathrm{P}$ & 9.2 & 0.063 & 13.6 & 99.3 \\
\hline $\mathrm{Cl}$ & 2495 & 189 & 5804 & 92.4 \\
\hline $\mathrm{SO}_{4}$ & 2454 & 141 & 5773 & 99.5 \\
\hline $\mathrm{Ca}$ & 80 & 0.92 & 234 & 98.8 \\
\hline $\mathrm{Mg}$ & 146 & 0.48 & 431 & 99.7 \\
\hline $\mathrm{K}$ & 821 & 41.5 & 2410 & $94 / 9$ \\
\hline $\mathrm{Na}$ & 1510 & 53.9 & 4210 & 96.4 \\
\hline Cr (total) & 0.07 & 0 & 0.334 & 100.0 \\
\hline $\mathrm{Fe}$ & 3.6 & 0 & 10 & 100.0 \\
\hline $\mathrm{Pb}$ & 0.126 & 0.008 & 0.45 & 93.7 \\
\hline $\mathrm{Mn}$ & 0.308 & 0 & 0.843 & 100.0 \\
\hline $\mathrm{Ni}$ & 0.418 & 0.016 & 1.12 & 96.2 \\
\hline COD & 2200 & 51 & 6150 & 97.7 \\
\hline Phenolics & 0.34 & 0.11 & 2.84 & 67.6 \\
\hline Conductivity & 1759 & 120 & 4120 & 93.2 \\
\hline $\mathrm{pH}$ & 6.58 & 6.36 & 7.95 & \\
\hline
\end{tabular}

Note: All results are in $\mathrm{mg} / \ell$ except for $\mathrm{pH}$ value and electrical conductivity $(\mathrm{mS} / \mathrm{m})$

\section{Performance of tubular cellulose acetate membranes for treatment of the leachate}

Permeate flux (PF) for two batch runs is shown in Fig. 3. The initial permeate flux was approximately $600 \mathrm{l} / \mathrm{m}^{2} \cdot \mathrm{d}$ and the flux decreased as a function of percentage water recovery as a result of the increased osmotic pressure of the feed at higher water recoveries. Almost identical results were obtained with the two runs that were conducted (up to approximately $70 \%$ water recovery). The initial CWFs and CWFs at the end of the runs were almost identical. This shows that membrane fouling should not be a serious problem and that it should be possible to control membrane fouling with flow reversal and sponge-ball cleaning.

The chemical composition of the RO feed, permeate and brine is shown in Table 2 .

A very good quality permeate could be produced with RO treatment of the leachate. The TDS of the leachate could be reduced from 8975 to $348 \mathrm{mg} / \ell$ ( $96.1 \%$ removal). Ammonianitrogen and COD, however, were only reduced from 882 to

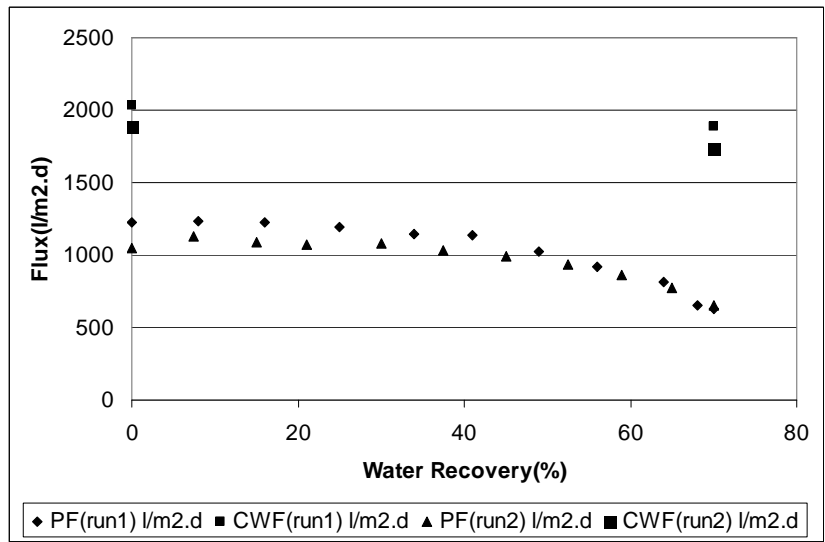

Figure 4

Permeate flux as a function of \% water recovery (polyamide membranes)

$82 \mathrm{mg} / \ell$ (90.7\% removal) and 2200 to $51 \mathrm{mg} / \ell$ (97.7\% removal), respectively. Therefore, the treated water quality complies with the discharge standards, with the exception of ammonia-nitrogen and COD.

\section{Performance of tubular polyamide membranes for the treatment of the leachate}

The permeate flux for two batch runs is shown in Fig. 4. The initial permeate flux was approximately $1200 \mathrm{l} / \mathrm{m}^{2} \cdot \mathrm{d}$ and the flux also decreased as a function of percentage water recovery. The permeate flux of the second run was slightly less than that of the first run. The CWFs at the end of the runs were slightly less than at the beginning of the runs. This might indicate that the polyamide membranes are more prone to membrane fouling than the cellulose acetate membranes.

The permeate flux through the polyamide membranes was significantly higher than that through the cellulose acetate membranes. Therefore, more product water should be produced with the polyamide membranes than with the cellulose acetate membranes.

The chemical composition of the RO feed, permeate and brine is shown in Table 3 .

Slightly higher TDS removals were obtained with the polyamide membranes $(97.7 \%)$ than with the cellulose acetate membranes (96.1\%). Conductivity removals were $96.9 \%$ for the polyamide and $93.2 \%$ for the cellulose acetate membranes. Similar ammonia-nitrogen removals were obtained with the polyamide (980 to $81 \mathrm{mg} / \ell, 91.7 \%$ removal) than with the cellulose 


\begin{tabular}{|l|c|c|c|c|}
\hline \multicolumn{5}{|c|}{$\begin{array}{c}\text { TABLE 3 } \\
\text { and brine }\end{array}$} \\
\hline Constituent & Feed & Permeate & Brine & $\begin{array}{c}\text { Removal } \\
\%\end{array}$ \\
\hline TDS & 7070 & 146 & 21755 & 97.9 \\
\hline TSS & 368 & 20 & 304 & 94.6 \\
\hline $\mathrm{NH}_{3}-\mathrm{N}$ & 980 & 81 & 1759 & 91.7 \\
\hline $\mathrm{PO}_{4}$-P & 6.91 & 0 & 10.1 & 100.0 \\
\hline $\mathrm{Cl}^{\mathrm{SO}}{ }_{4}$ & 2.625 & 33.9 & 7062 & 98.7 \\
\hline $\mathrm{Ca}$ & 149 & 0 & 433.6 & 100.0 \\
\hline $\mathrm{Mg}$ & 70.6 & 0.21 & 56 & 99.7 \\
\hline $\mathrm{K}$ & 141 & 0.13 & 503 & 99.9 \\
\hline $\mathrm{Na}$ & 1150 & 11.5 & 2630 & 99.0 \\
\hline $\mathrm{Cr}$ (total) & 1620 & 12.5 & 5200 & 99.2 \\
\hline $\mathrm{Fe}$ & 0.17 & 0.001 & 0.43 & 99.4 \\
\hline $\mathrm{Pb}$ & 3.16 & 0.009 & 8.47 & 99.7 \\
\hline $\mathrm{Mn}$ & 0.126 & 0 & 0.354 & 100.0 \\
\hline $\mathrm{Ni}$ & 0.382 & 0 & 0.879 & 100.0 \\
\hline $\mathrm{COD}$ & 0.2 & 0.002 & 0.753 & 99.0 \\
\hline $\mathrm{Phenolics}$ & 2000 & 46 & 7200 & 97.7 \\
\hline $\mathrm{Conductivity}$ & 1719 & 53 & 4140 & \\
\hline $\mathrm{pH}$ & 8.2 & 9.2 & 8.2 & \\
\hline $\mathrm{Not}:$ All & 0.34 & 0.04 & 1.49 & 96.9 \\
\hline
\end{tabular}

Note: All results are in $\mathrm{mg} / \mathrm{\ell}$ except for $\mathrm{pH}$ value and electrical conductivity $(\mathrm{mS} / \mathrm{m})$

acetate membranes ( 882 to $82 \mathrm{mg} / \ell, 90.7 \%$ removal). However, better $\mathrm{Cl}^{-1} \mathrm{SO}_{4}^{-2}, \mathrm{Ca}, \mathrm{Mg}, \mathrm{K}$ and $\mathrm{Na}$ removals were obtained (98 to $100 \%$ removal). Better $\mathrm{Pb}, \mathrm{Ni}$ and phenol removals were also obtained with the polyamide membranes. The treated water quality complies with the discharge requirements, with the exception of ammonia-nitrogen and COD. It further appears that the polyamide membranes should perform somewhat better than the cellulose acetate membranes for the desalination/ concentration of the leachate.

\section{The fouling potential of the leachate for the cellulose acetate membranes (feed-and-bleed tests)}

Permeate flux as a function of time is shown in Fig. 5. The initial permeate flux was approximately $550 \mathrm{l} / \mathrm{m}^{2} \cdot \mathrm{d}$ and declined as a result of membrane fouling. The permeate flux declined to approximately $200 \mathrm{\ell} / \mathrm{m}^{2} \cdot \mathrm{d}$ after $230 \mathrm{~h}$ of operation and then increased to approximately $300 \mathrm{l} / \mathrm{m}^{2} \cdot \mathrm{d}$ (approximately $350 \mathrm{~h}$ ) of operation. This increase in permeate flux could be ascribed to a decrease in the feed concentration.

The initial CWF was about $700 \mathrm{\ell} / \mathrm{m}^{2} \cdot \mathrm{d}$ (Fig. 5) and declined to $522 \mathrm{l} / \mathrm{m}^{2} \cdot \mathrm{d}$ at the end of the run. It is interesting to note that the CWF remained at approximately $500 \mathrm{l} / \mathrm{m}^{2} \cdot \mathrm{d}$ from $250 \mathrm{~h}$ of operation and slightly higher until the end of the run. Therefore, it appears that it should be possible to control membrane fouling with regular chemical cleaning.

Various membrane cleaning agents were evaluated for fouling control. All the cleaning agents tested had a positive effect on membrane cleaning (Fig. 5). It appears that the best membrane cleaning was achieved was acid (NA, CitA and PhosA) and chemical (EDTA and SLS and/or STPP and EDTA) cleanings. Sponge ball (SB) recycling also had a positive effect on membrane cleaning. However, more detailed studies will be required to determine the best membrane cleaning strategy for fouling control.

The initial and final (after $500 \mathrm{~h}$ of operation) permeate fluxes as a function of percentage water recovery are shown in Fig. 6 . The permeate flux after approximately $500 \mathrm{~h}$ of operation was somewhat lower than the initial permeate flux. This indicates permanent membrane fouling. However, membrane fouling could be expected to occur in the last RO stages as simulated with the feed-and-bleed RO system and the reduction in permeate flux was not substantial. The CWF measured before and after the run on the fouled membrane surface was approximately the same. The CWF at the end of the second run, however, was significantly lower than the initial CWF on the new membrane. This indicates membrane fouling.

The TDS and conductivity removals were $77.1 \%$ and $64.2 \%$ (after $500 \mathrm{~h}$ of operation) (Schoeman and Steyn, 2004). Therefore, the salinity removal has decreased significantly from the first batch run $(96.1 \%$ TDS and $93.2 \%$ conductivity removal on a clean surface (Table 2)). This showed that membrane fouling has taken place and this fouling will affect the quality of the treated leachate adversely unless properly controlled.

\section{The fouling potential of the leachate for the poly- amide membranes (feed-and-bleed tests)}

Permeate flux as a function of time is shown in Fig. 7. The initial permeate flux was about $1200 \mathrm{l} / \mathrm{m}^{2} \cdot \mathrm{d}$ and decreased as a result of membrane fouling. Permeate flux decreased to approximately $500 \mathrm{\ell} / \mathrm{m}^{2} \cdot \mathrm{d}$ after 100 hours of operation and remained at $500 \mathrm{\ell} / \mathrm{m}^{2} \cdot \mathrm{d}$ until about 200 hours of operation and decreased to approximately $300 \ell / \mathrm{m}^{2} \cdot \mathrm{d}$ after $330 \mathrm{~h}$ of operation. Permeate flux reached a low of about $100 \mathrm{l} / \mathrm{m}^{2} \cdot \mathrm{d}$ after $400 \mathrm{~h}$ of operation and remained at about 200 to $250 \mathrm{l} / \mathrm{m}^{2} \cdot \mathrm{d}$ until the end of the run.

The initial CWF was about $1900 \mathrm{\ell} / \mathrm{m}^{2} \cdot \mathrm{d}$ and declined as a function of time as a result of membrane fouling. The CWF was measured as $451 \mathrm{l} / \mathrm{m}^{2} \cdot \mathrm{d}$ at the end of the run (501 h of operation). It is interesting to note that the CWF remained approximately constant from $400 \mathrm{~h}$ until the end of the run (501 h). Cleaning of the membranes with acid, Ultrasil 10 and preservation of the membranes had a significant effect on the CWF. Therefore, it appears that it should be possible to control membrane fouling with regular chemical cleaning.

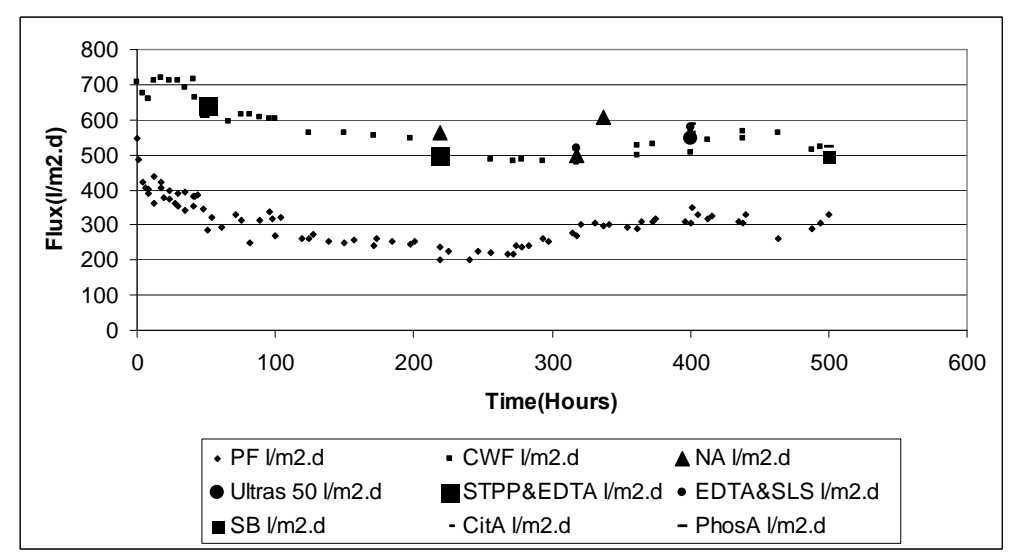

Figure 5

Permeate flux as a function of time 


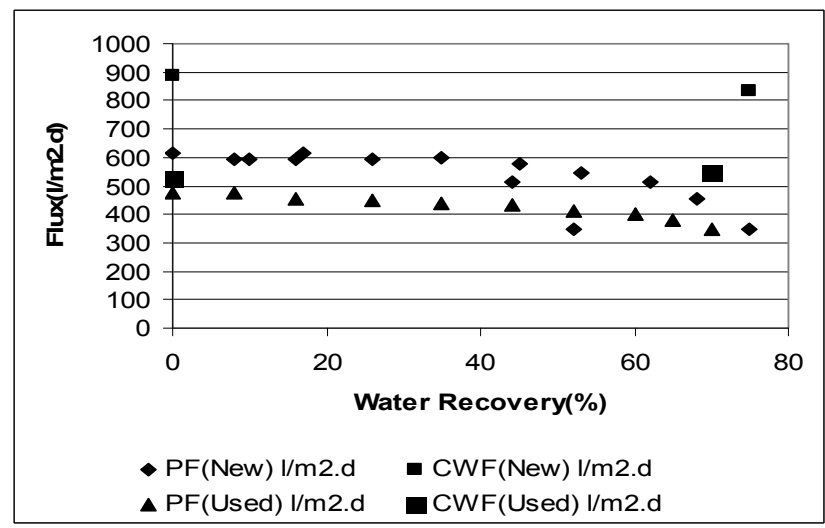

Figure 6

Initial and final (after $500 \mathrm{~h}$ of operation) permeate flux as a function of $\%$ water recovery

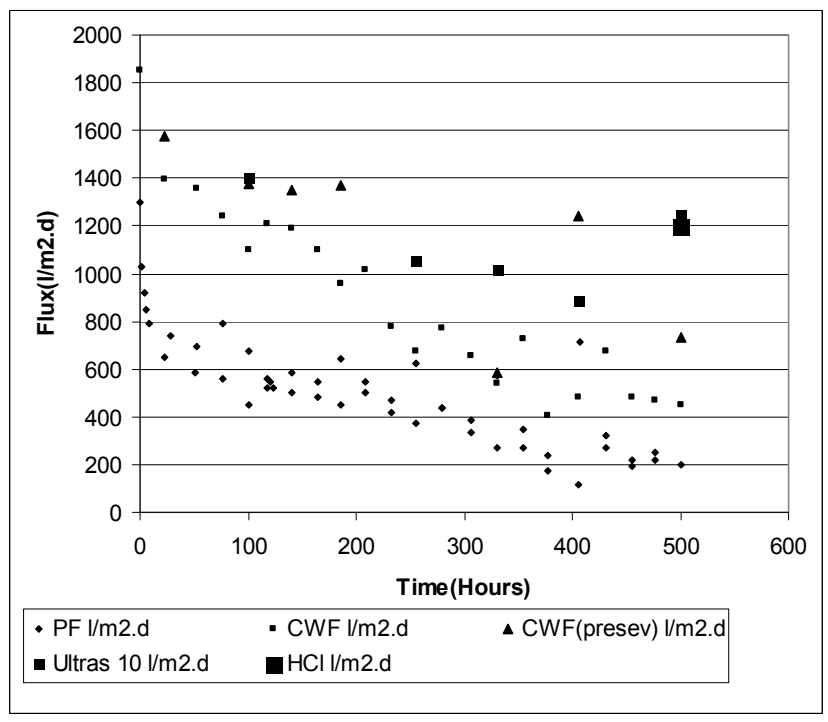

Figure 7

Permeate flux as a function of time

The initial and final (after $500 \mathrm{~h}$ of operation) permeate fluxes as a function of time are shown in Fig. 8 (batch run). The permeate flux after approximately $500 \mathrm{~h}$ of operation was again somewhat lower than the initial permeate flux. This can be expected due to membrane fouling. The reduction in permeate flux, however, was not that much. The CWF at the end of the second run was again lower than the initial CWF on the new membrane. This indicates membrane fouling. It is further interesting to note that acid cleaning of the membranes increased CWF significantly. Therefore, acid cleaning of the membranes will be required from time to time together with cleaning with Ultrasil 10.

The chemical composition of the leachate after $500 \mathrm{~h}$ of operation (batch test) showed that the permeate quality that was produced after membrane fouling was still excellent (Schoeman and Steyn, 2004). Conductivity removal was $93.4 \%$ (TDS removal 96.6\%). The TDS and conductivity removals on a fresh membrane surface were $97.9 \%$ and $96.6 \%$, respectively (Table 3 ). Therefore, an excellent quality water could be produced with $\mathrm{RO}$ treatment of the leachate using polyamide membranes.

\section{Economics}

The capital and operation costs of a $250 \mathrm{k} \ell / \mathrm{d}$ RO plant (feed)

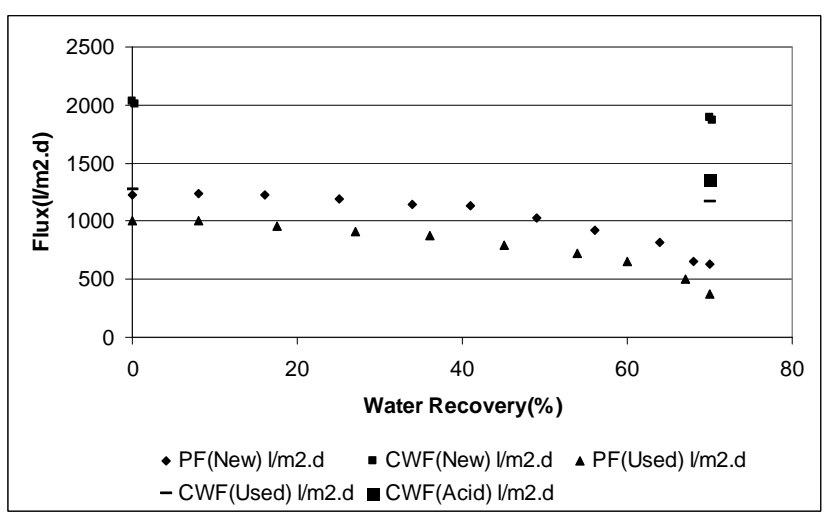

Figure 8

Initial and final (after $500 \mathrm{~h}$ of operation) permeate flux as a function of \% water recovery

\begin{tabular}{|c|c|c|}
\hline \multicolumn{3}{|c|}{$\begin{array}{c}\text { TABLE } 4 \\
\text { Estimated capital and operational cost for } \\
\text { treatment of Bisasar Road MSWL }\end{array}$} \\
\hline Plant type & $\begin{array}{l}\text { Capital cost } \\
\text { (MR) }\end{array}$ & $\begin{array}{c}\text { Operational } \\
(\mathrm{R} / \mathrm{k} \ell)\end{array}$ \\
\hline Tubular (cellu & 1.95 & 11.45 \\
\hline Tubular (polyamide) & $8.1^{(1)}$ & 16.24 \\
\hline
\end{tabular}

(1): Total plant from overseas supplier

(2): Only membranes, modules and frames from overseas supplier CA membranes: Membrane life time 2 years; PA membranes life time 18 months; 1 British pound $=$ R16.20

to treat the MSWL at Bisasar road are summarised in Table 4 (Schoeman et al., 2004).

\section{Conclusions}

- $\quad$ The TDS of the leachate could be reduced from 8975 to 348 $\mathrm{mg} / \ell(96.1 \%$ removal) using cellulose acetate membranes. Therefore, an excellent quality water could be produced with $\mathrm{RO}$ treatment of the leachate. The quality of the RO product with the exception of ammonia-nitrogen and COD complies with the discharge quality requirements (water environment and sewer). Cellulose acetate membranes therefore have the potential to produce a very good quality water.

- Higher TDS removals were obtained with the polyamide membranes $(97.9 \%)$ than with the cellulose acetate membranes (96.1\%). Better lead, nickel and phenol removals were also obtained with the polyamide membranes. The quality of the RO product with the exception of ammonianitrogen and COD complies with the discharge quality requirements (water environment and sewer). Polyamide membranes therefore also have the potential to produce a very good quality water.

It should be possible to control membrane fouling (cellulose acetate membranes) with regular acid (nitric, citric and phosphoric) and chemical (EDTA and SLS and/or STPP and EDTA) cleaning. The CWF and the permeate fluxes remained at approximately 500 and $300 \mathrm{l} / \mathrm{m}^{2} \cdot \mathrm{d}$, respectively, after about $500 \mathrm{~h}$ of operation (feed-and-bleed). Permeate flux was about $20 \%$ lower after $500 \mathrm{~h}$ of operation as a result of membrane fouling. The TDS removal was 77.1\% after $500 \mathrm{~h}$ of operation (batch test). The TDS removal was $96.1 \%$ on a fresh membrane surface. Therefore, a significant reduction in salinity removal has occurred as a result of membrane fouling and this will have an adverse effect on 
the quality of the treated leachate unless membrane fouling is properly controlled with regular chemical cleanings.

- It should also be possible to control membrane fouling with regular acid (hydrochloric) and chemical (Ultrasil 10) cleaning using the polyamide membranes. The CWF and the permeate fluxes remained at approximately 500 and $200 \mathrm{l} / \mathrm{m}^{2} \cdot \mathrm{d}$, respectively, after about $500 \mathrm{~h}$ of operation (feed-and-bleed). The permeate flux was also about $20 \%$ lower after $500 \mathrm{~h}$ of operation than was the case with the cellulose acetate membranes. The TDS removal was $96.6 \%$ after $500 \mathrm{~h}$ of operation (batch test). The TDS removal was $97.9 \%$ on the fresh membrane (batch test). Therefore, the reduction in salinity removal after $500 \mathrm{~h}$ of operation was significantly less than with the cellulose acetate membranes.

- It could be proposed that a biological treatment step be added in-line to provide for the effective total treatment of landfill leachates, in particular by the sequencing batch reactor (SBR) method. Biological aerobic processes using SBRs have demonstrated high efficiencies in the removal of ammonia-nitrogen and biodegradable BOD and COD. Most of the membrane fouling caused by organics in the leachate should also be eliminated in the process.

The estimated capital and operational costs to treat $250 \mathrm{~m}^{3} / \mathrm{d}$ of MSWL with different RO plants are (Schoeman et al., 2004):

Cellulose acetate membranes - capital R1.95 m.; operational $\mathrm{R} 11.45 / \mathrm{k} \ell$

Polyamide membranes - capital R8.1 m.; operational R16.24/ $\mathrm{k} \ell$

\section{Acknowledgement}

The very capable technical assistance of Mr. André Steyn is acknowledged.

\section{References}

BELKHOUCHE N, DIDI MA, TAHA S and FARES NB (2009) Zinc rejection from leachate solutions of industrial solid waste - effects of pressure and concentration on nanofiltration membrane performance. Desalination 239 58-65.

GAU SH and CHANG FS (1996) Improved Fenton method to remove recalcitrant organics in landfill leachate. Water Sci. Technol. 34 455-462.

GIERLICH HH and KOLBACH J (1998) Treating landfill leachate in European countries. Pollut. Eng. (August) 10-14.

HURD S, KENNEDY RJ, DROSET RL and KUMAR A (2001) Low pressure reverse osmosis treatment of landfill leachate. J. Solid Waste Technol. Manage. 27 (1) 1-14.

IMAI A, INAMORI Y and SUDO R (1998) Effect of pre-ozonation in refractory leachate treatment by biological activated carbon fluidized feed process. Environ. Technol. 19 213-223.
KNOX K and JONES PH (1979) Complexation characteristics of sanitary landfill leachates. Water Res. 13 839-846.

LAITINEN N, LUONSI A and VILEN J (2006) Landfill leachate treatment with sequencing batch reactor and membrane bioreactor. Desalination 191 86-91.

LIM YN, SHAABAN MG and YIN CY (2009) Treatment of landfill leachate using palm shell-activated carbon column: Axial dispersion modelling and treatment profile. Chem. Eng. J. 146 (1) 86-89.

LEMA JM, MENDEZ R and BLAZQUES R (1988) Characteristics of landfill leachates and alternatives for their treatment: Ann. Rev. Water Air Soil Pollut. 40 223-250.

LIN SH and CHANG CC (2000) Treatment of landfill leachate by combined electro-fenton oxidation and sequencing batch reactor method. Water Res. 34 (17) 4243-4249.

PERCIVAL LJ, SENIOR E and SOUTHWAY (1997) Treatment of a high-strength leachate from a closed co-disposal landfill site in South Africa. Water SA 23 (4) 411-418. http://www.wrc.org.za/ downloads/watersa/1997/Vol\%2023 no 4/1070\%20abstract.pdf

PETERS TA (1998) Purification of landfill leachate with reverse osmosis and nanofiltration. Desalination 119 289-293.

RAUTENBACH R and LIN TH (1996) High pressure reverse osmosis and nanofiltration, a zero discharge process combination for the treatment of wastewater with severe fouling/scaling potential. Desalination 105 63-70.

RIVAS FJ, BELTRAN F, CARVALHO F, GIMENO O and FRADES J (2005) Study of different integrated physical-chemical and adsorption processes for landfill leachate remediation. Ind. Eng. Chem. Res. 44 2871-2878.

ROBINSON H (2000) Leachate treatment options for landfill leachate. Proc. $1^{\text {st }}$ Int. Training Seminar, Control Management and Treatment of Landfill Emissions. 6-8 December 2000, University of Natal Civil Engineering Programme, Durban, South Africa.

SCHOEMAN JJ, STEYN A, SLABBERT JL and VENTER EA (2004) Treatment of Landfill Leachate from Hazardous and Municipal Solid Waste. WRC Report No. 1167/1/03. Water Research Commission, Pretoria, South Africa.

STRACHAN LJ, TROIS C, ROBINSON HD and OLUFSEN JS (2000) Appropriate biological treatment of landfill leachates with full nitrification and denitrification. Proc. WISA (Water Institute of South Africa) Bienn. Conf. Exhib. 28 May to 1 June 2000, Sun City, South Africa.

STRACHAN LJ, ROBINSON HD, HARRIS GR and OLUFSEN JS (2004) Full scale, on-site, complete treatment solution for landfill leachate: A first for South Africa. Wastecon 2004 Conference, Cape Town, South Africa, 5 to 7 October 2004. IWMSA 1 39-48.

USHER BH, PRETORIUS JA, DENNIS I, JOVANOVIC N, CLARKE S, CAVE L, TITUS R and XU Y (2004) Identification and Prioritisation of Groundwater Contaminants and Sources in South Africa's Urban Catchments. WRC Report No 1326/1/04. Water Research Commission, Pretoria, South Africa.

USHIKOSHI K, KOBAYASHI T, UEMATSU K, TOJI A, KOJIMA D and MATSUMOTO K (2002) Leachate treatment by reverse osmosis. Desalination 150 121-129.

WINTGENS T, LYKO S, SPALDING G and MELIN T (2006) Behaviour of bulk and trace organics in a full scale membrane bioreactor for landfill leachate treatment. Proc. Water Environment Federation $79^{\text {th }}$ Annual Technical Exhibition and Conference. 4781-4788. 